\title{
Law Enforcement Against Fighting Group By Native In West Papua
}

\author{
Irna Indira Ratih \\ Faculty of Law, Hasanuddin University \\ Jln. Perintis Kemerdekaan Km.10, Tamalanrea, Makassar, 90245, Indonesia \\ Tel./Fax: +62-411-587219 Email: indira.irna@yahoo.com
}

\begin{abstract}
The fundamental research conducted by looking at the phenomenon of group fights and how ethnocentrism and conflict influence each other indigenous ethnic groups in West Papua. This study used descriptive qualitative method, through field studies (indepth interviews) and literature study. The results showed that with a low level of understanding of the history of the conflict supported ever experienced by the perpetrators of communication, there is a trend of negative information transformation process to be effective. So as to absorb the negative information, aspects of ethnocentrism group members appear. The emergence of these aspects lead to the awareness and solidarity groups to join forces in-group. Other findings also showed that the factors causing conflict among indigenous ethnic groups in West Papua can be summarized in two points, namely; The first tendency puts another group at a level lower social interaction, and the second is the attempt appointment of existence itself by an ethnic group seeking recognition coupled behavior (respect) from inside and outside the group by scapegoating other groups. In the indigenous ethnic group communication, attitude and behavior aspects play a role in the formation of a negative message, based on the main factors. The tendency of formation of the group because of its frequency along the occurring hereditary. Related conflict and ethnocentrism, can be drawn that the results of the analysis found the substance also major causal relationship. Where, a communal conflict can result from the manifestation of ethnocentrism aspects into forms of behavior conflict. In contrast with the presence of conflict can also strengthen or weaken ethnocentrism.
\end{abstract}

Keywords: Fighting Group; Civil War; Crime

\section{INTRODUCTION}

Papua is one area in Indonesia that still keep a wide range of social problems. One of the social problems that until now have been there and is still happening is social conflict. The social conflict in Papua is very diverse and includes all aspects of life, ranging from social, cultural, political and economic. Conflicts, which led to war the tribe or group.

Basically, war and ethnic groups of which occur in remote areas due to several problems Timika, in accordance with the characteristics of the problems that can 
harm and disrupt even break the rules and norms that apply to existing tribes. Illicit problem or infidelity, murder, unnatural deaths, and the deep resentment is one of the causes of war Inland tribes in Timika area.

Tribal war is one of the serious social problems faced by some of the local tribes and have a very broad social impact. War and ethnic groups can lead to family ties and relationships between parts become loose, the creation of conditions of discomfort. Regional development will experience volatile and hampered, economy society and activity offices, schools participate hampered and there are some another sectors in participate hampered.

Papua, as well as other provinces in Indonesia, have ethnic and cultural diversity. Some of them are well-known is the Asmat and Dani. However, Papua not solely revolve around the two ethnic groups, there are dozens of other tribes who lived in the land of Papua complete with culture and customs. ${ }^{1}$

However, with the variety of tribes in Papua, there are rare inter-ethnic conflict. Moreover, the views of the state of tribal communities in Papua in general can still

\footnotetext{
${ }^{1}$ http://wardaturrochmah.web.unej.ac.id/2016/06/20/k onflik-budaya-korelasi-antara-budaya-dengan-terjadinyakonflik-antar-etnis/, Accessed on, 20 Mei 2016
}

be categorized as primitive and less educated. Conflict becomes the most common place when their disagreement, competition for land, and others. Moreover, viewed from the cultural ancestors of the tribes that did have a culture war that is very thick.

Further impacts of war and ethnic groups it is the emergence of new social problems in the tribes involved in tribal wars such as the maintenance of animosity between the router generation due to the compensation system. Material losses such as the burning of houses and looting of other valuable possessions will have an impact on the rise of poverty and social inequality in the society who were targeted victims of tribal warfare. $^{2}$

Political conflict, one of them happened because of concerns with discrimination or classifications among ordinary people in Papua with the immigrants as well as government officials and political elites. For that there is some

\footnotetext{
${ }^{2}$ Dani ethnic groups in conflict with Moni tribe, had been living in the area New Utikini approximately 16-17 years there. Whereas before there Utikini Baru, their areas of origin namely Utikini own village in the mountainous areas there is a genuine area of origin of the Dani tribe itself. Massive migration arising from the activities of PT Freeport Indonesia was lead they moved to lowland now New Utikini. Which is territorially the lands or territories of indigenous Kamoro. http://www.kompasiana.com/keriting/konflik-suku-danimoni-konflik-paling-lucu-dipapua_54f8020ca33311641e8b4fe3, Accessed on 20 Mei 2016
} 
of the things done by the government such as :

1. Avoid supporting faith-based activities that clearly have a political agenda, so as not to exacerbate the problems that already exist, and instruct the armed forces and police to ensure that the personnel who served in Papua is not seen favor one side.

2. Avoid funding any groups that preach exclusivity or enmity toward other faiths.

3. Ensure public debate on the percentage of jobs for Papuans and the impact on further migration of non-Papuans before agreeing to further division of administrative regions.

4. Reject discriminatory local regulations and remove policies that marginalized people of Papua.

The handling of a war in the Mimika region should be more focused on the handling of customs, where the cultural values as a basis for resolving the conflict. Handling this kind of effort to achieve a balance between the victims of the two tribes involved in the war. Having achieved a balance, conflict resolution and then enforced through customs and cultural ceremony called ceremony burn stone.
ANALYSIS AND DISCUSSION Sociological Against War And Ethnic

\section{Groups}

Crime according to sociological is actions contrary to the morals of humanity, to the detriment of society formulated and specified in the course of criminal laws. Then in the sociological sense, the crime also includes human behavior, although not specified in the legislation essentially by citizens perceived and interpreted as a behavior or actions that economically and psychologically attacked or harm people and harm the feelings of decency in society.

Factors of the crime, sociological look for reasons for the differences in terms of crime rate in the social environment. These theories can be grouped into three categories, such as :

a. Anomie (absence of norms) or strain (strain)

b. Cultural Deviance (cultural biases)

c. Social Control (social control)

E.H. Sutherland theorize called Differential Association Theory as a theory of the causes of crime. There are 9 proportions in explaining the that theory :

1) Criminal behavior is learned (learned criminal behavior)

2) Criminal behavior is learned in interaction with other persons in a process of communication (learned 
criminal behavior in interaction with others in the communication process).

3) The principle part of the learning of criminal behavior within intimate personal Occurs groups (the most important part in the study criminal behavior that occurs within groups of people intimate / close).

4) When the Criminal behavior is learned, the learning includes techniques of committing the crime, the which are sometimes very complicated, sometimes very simple, and the specific direction of motives, drives, rationalization, and attitude (when the behavior of criminals learned, the lessons included techniques of committing a crime, which is sometimes very easy and specific direction of motives, drives, rationalizations, and attitudes).

5) The specific direction of motives and drives is learned from definitions of the legal codes as favorable or unfavorable (specific direction of motives and impulses are learned through the definitions of the rules of law whether it is profitable or not).

6) A person Becomes delinquent because of an excess of definitions favorable to violation of law over definitions unfavorable to violation of law (a person becomes delinquent because definitions are favorable for breaking the law is stronger than the definitions that are not profitable to break the law ).

7) Differential association may vary in frequency, duration, priority, and intensity (differential association that may vary in frequency / density, length, priority, and intensity).

8) The process of learning criminal behavior by association with criminal and anti criminal patterns involves all of the mechanisms that are involved in any of learning (process of studying criminal behavior through association with patterns of crime and anti-crime involves all the mechanisms that apply in every the learning process).

9) While criminal behavior is an expression of general needs and values, it is not explains by Reviews those general needs and values, since noncriminal behavior is an expression of the same needs and values (even if criminal behavior is an expression of the needs and values -value general, criminal behavior can not be explained by the needs and common values such as 
behavior non criminal also an expression of the needs and the same value).

Some of the social aspects by the 8th UN Congress 1990 in Havana Cuba, was identified as a factor conducive to the cause of crime between Poverty, unemployment, illiteracy (ignorance), the absence or lack of adequate housing and education and training systems that do not fit or match.

a) Increasing the number of people who do not have prospects (expectations) for 81 social integration process, as well as imbalance- worsening social inequality.

b) Loosening of social ties and family.

c) The circumstances / conditions that make it difficult for people who emigrated to the cities or to other Countries.

d) Damage to or destruction of indigenous cultural identity, which together with their racism and discrimination led to the loss / weakness of social, welfare and work environment.

e) Descending or pullback quality urban environment that encourages an increase in crime and reduced services for areas of environmental facilities / neighbors. f) Difficulties for people in modern society to integrate as appropriate in their communities, their families, workplace or school environment.

g) Abuse of alcohol, drugs and others that use is also required because of the factors mentioned above.

\section{Tribal War and Fighting Group as a crime}

Fighting is defined as opposition groups that are directly and constituted between individuals or groups to achieve the same goal. This is due to the counterparty are considered very important in achieving objectives and this is because of the conflict inward orientation of the parties is more important than the object, to be achieved in reality, because of the growth of hatred deepening, the achievement of objectives often secular, while the opposing side facing away more important ".

Factors underlying conflict between groups fighting is an event that is an encouragement where encouragement can influence and lead to conflict between groups fighting.

Dahrendof suggests the characteristics of conflicts in social organization such as:

a. The social system is always in a state of conflict 
b. These conflicts are caused

c. because of their conflicting interests that can not be prevented in the social structure.

d. These interests tend to polarize into two conflicting groups.

e. Interests conflicting deferential reflect the distribution of power among the ruling groups and controlled

f. Explanation conflict will lead to new devices conflicting interests, which under certain conditions give raise to conflict.

g. Social change is the consequences of a conflict that can not be prevented in various types of patterns that have been institutionalized

Some cases of fights between groups sometimes starts the problem with an individual who represents one of the groups. Information is spread in such a way finally and eventually formed a group consciousness. This is called Soekanto as a form of consciousness in-group and the out group.

Awareness in the group is a social group in which the individual identifies himself. Out group is a social group that the individual is defined as the opponent in its group. Feeling in the group and out group constituted with an attitude called ethnocentric, namely the presumption that habits are the best in their group compared with the other group.

\section{Perpetrators of War Crimes Parts Or Violence Group}

Who are the perpetrators especially actors "mass brutality". Perpetrator of the lower social classes (lower class) wrote or also by the upper class (upper class) also serves as the perpetrator. How is the case with the "provocateurs" who are currently widely touted in riots and acts of certain crimes, always said there were acts as "provocateurs", usually is "elite" who have political gain or other authority "lend a hand "lower class people to do anything to achieve his or her group. During this time many criminological theories assume that the perpetrators of violent crime and the "brutality masses" only on the "blue collar" only, while the "white collar" is not involved in crime.

\section{CLOSING}

Tribal wars and fights that occur in the Earth groups Papua occur due to social conflict and widespread impact on life in Papua. Factors causing occurrence, caused social Systems always in a state of conflict, the conflicts due to the conflicting interests that can not be prevented in the social structure. Lack of awareness of the 
individual against his own group to maintain self-esteem and groups, where the habit in the group is the best and it is this, which complicate the Peace in Papua.Tribal war is not merely the actions of any and friction that occurs between the groups in Papua, but the government also took the position that an important war. Policies that marginalize tribes in Papua is one of the causes of tribal warfare due to lack of jobs for the indigenous people of Papua, this leads to social jealousy between communities in Papua.

\section{BIBLIOGRAPHY}

A.F Saifuddin. (1986). Conflict and Integration (Difference Religion). Jakarta: Rajawali Press

Hardiman, Understanding the roots of mass violence, July 282008 in XI
Congress, Congress on Crime Prevention and Criminal Justice Site Mimika district government.

Al-Rahab, Amarudin. (2010). Heboh Papua: Rahasia Perang, Trauma dan Separatis. Komunitas Bambu. Depok

Soerjono Soekanto. (2007). Pengantar Soisologi. Jakarta: PT. King Grafindo Persada.

U.S. Alam. (2010). Pengantar Kriminologi. Makassar: Reflections Yesmil Anwar and Adang. 2013. Kriminologi. Bandung: Rafika Aditama Budi

\section{Website:}

http://wardaturrochmah.web.unej.ac.id/201 6/06/20/konflik-budaya-korelasiantara-budaya-dengan-terjadinyakonflik-antar-etnis/,

http://www.kompasiana.com/keriting/konfl ik-suku-dani-moni-konflik-palinglucu-dipapua_54f8020ca33311641e8b4fe3 